\title{
First underwater sighting of Shepherd's beaked whale (Tasmacetus shepherdi)
}

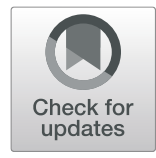

\author{
Christopher D. H. Thompson ${ }^{1 *}$ (D, Phil J. Bouchet ${ }^{1,2}$ and Jessica J. Meeuwig ${ }^{1}$
}

\begin{abstract}
Here we describe the first underwater sighting of Shepherd's beaked whale (Tasmacetus shepherdi). Two individuals were observed together on video footage obtained via mid-water stereo-Baited Remote Underwater Video Systems (BRUVS) deployed off the coast of Inaccessible Island, Tristan da Cunha, in the South Atlantic. This observation constitutes the first recorded live sighting of this species in the waters of Tristan da Cunha since 2002 and provides further evidence for the persistence of a population of this species in the region. The observed individuals lacked the dark flipper stripe observed in previous descriptions, indicating that the species may exhibit greater variation in pigmentation than previous records indicate. The planned implementation of a marine reserve in the region along with the current low level of fishing pressure and remote location of this archipelago provide a good context to ensure the appropriate management and protection of this rare species. The recent establishment of an ongoing mid-water stereo-BRUVS monitoring programme, in concert with other methods targeted at marine mammals, may yield further information about this little known species and aid in informing management decisions in the future.
\end{abstract}

Keywords: Tristan da Cunha, South Atlantic, Whale, Cetacean, Pigmentation, BRUVS, Marine reserve

\section{Background}

First described by Oliver (1937) from a female specimen stranded in Ohawe, New Zealand on November $7^{\text {th }}$ 1933, the Shepherd's beaked whale (Tasmacetus shepherdi) is one of the least understood cetaceans in the world (Mead 1989, 2002). The species is classified as data deficient on the IUCN Red List (Taylor et al. 2008) and thought to be found in a circumpolar band that stretches across the deep, cold-temperate waters of the Southern Ocean generally between $30^{\circ} \mathrm{S}$ and $46^{\circ} \mathrm{S}$ (Donnelly et al. 2018; MacLeod et al. 2006; Mead 2002). Current knowledge of the distribution patterns and habitat preferences of Shepherd's beaked whales is derived from a small number of stranding records and rare, opportunistic visual sightings at the surface. It is unclear whether low encounter rates reflect low abundance, low detectability, or both.

Pitman et al. (2006) summarised species observations until 2005. These records consisted of 42 strandings and five unconfirmed live sightings at the surface. Strandings

\footnotetext{
* Correspondence: chris.d.h.thompson1@gmail.com

${ }^{1}$ Marine Futures Lab, School of Biological Sciences M092, The University of Western Australia, Crawley, WA 6009, Australia

Full list of author information is available at the end of the article
}

were reported from New Zealand and the Chatham Islands (24 records), Argentina (7), Tristan da Cunha (6), Australia (3) and the Juan Fernandez Islands (2). Since 2005, stranding records for a single adult male in February 2008 from Golfo San Jorge, Santa Cruz Province, Argentina (Hevia et al. 2012) and a single individual on 10 November 2008 in Shark Bay, Western Australia $\left(26.33^{\circ} \mathrm{S}, 113.27^{\circ} \mathrm{E}\right)$ have been reported, the latter constituting the northernmost record for this species (Holyoake et al. 2013). In addition, a total of 13 vessel-based and five aerial sightings of Shepherd's beaked whales were obtained in the southern Australian and New Zealand regions from 2008 to 2017 (Donnelly et al. 2018; Miller et al. 2012). Of these surveys, several conducted in the Otago Canyons resulted in observations over different seasons, suggesting that this species may be found in localised areas of high abundance (Donnelly et al. 2018).

In the South Atlantic, the Shepherd's beaked whale is known to inhabit the waters of Tristan da Cunha (37.11 $\left.\mathrm{S}, 12.28^{\circ} \mathrm{W}\right)$ and associated islands. Tristan da Cunha is a British Overseas Territory and is the most remote inhabited island in the world. Strandings have been recorded within short time intervals (i.e. 6 months apart)

(C) The Author(s). 2019 Open Access This article is distributed under the terms of the Creative Commons Attribution 4.0 International License (http://creativecommons.org/licenses/by/4.0/), which permits unrestricted use, distribution, and 
suggesting that the area is regularly used (Pitman et al. 2006). Available stranding archives consist of: (i) two males on the beach south of Anchorstock Point, 15 April 1983 (ca. $37.12^{\circ} \mathrm{S}, 12.35^{\circ} \mathrm{W}$ ), (ii) one individual at Dead Man's Beach, Stony Hill Point, 13 October 1984 (ca. $37.17^{\circ} \mathrm{S}, 12.29^{\circ} \mathrm{W}$ ), (iii) two individuals at Runaway Beach, 9 December 1987 (ca. 37.09 ${ }^{\circ} \mathrm{S}, 12.34^{\circ} \mathrm{W}$ ), (iv) one individual at Noisy Beach 1995 (ca. $37.13^{\circ} \mathrm{S}, 12.23^{\circ} \mathrm{W}$ ), and (v) two individuals close to the Settlement, 13 January $2012\left(37.06^{\circ} \mathrm{S}, 12.30^{\circ} \mathrm{W}\right)$ (Best et al. 2014; Pitman et al. 2006). Other sightings consist of aerial photographs of two groups taken on 17 November 1985 between Nightingale and Inaccessible Islands, the first comprising 4 individuals $\left(37.30^{\circ} \mathrm{S}, 12.53^{\circ} \mathrm{W}\right)$ and the second six (ca. $\left.37.30^{\circ} \mathrm{S}, 12.57^{\circ} \mathrm{W}\right)$, as well as a sighting of $4-5$ individuals at Quest Bay, Gough Island (located ca. $400 \mathrm{~km}$ to the SE of the main island group), on 27 October 2002 $\left(40.32^{\circ} \mathrm{S}, 09.88^{\circ} \mathrm{W}\right)$ (Pitman et al. 2006) (Fig. 1).

Here, we report what we believe to be the first underwater sighting of Shepherd's beaked whale globally and the first live sighting of the species in Tristan da Cunha since 2002 (Pitman et al. 2006).

\section{Results}

Two individuals were observed in situ during a scientific expedition to Tristan da Cunha undertaken jointly by the National Geographic Pristine Seas Programme and the Royal Society for the Protection of Birds (RSPB) on


Fig. 1 Shepherd's beaked whale (Tasmacetus shepherdi) ocurrence in the South Atlantic. The top panel represents relative probabilities of occurrence (on a scale of 0 to 1) for Shepherd's beaked whale Tasmacetus shepherdi derived from the relative environmental suitability (RES) model developed by (Kaschner et al. 2006). Values were retrieved from the AquaMaps online platform (Kaschner et al. 2008). Low probability values are shaded in blue, and high ones in gold. The bottom panel is a map of published Shepherd's beaked whale records within the Tristan da Cunha Island group and Gough Island (inset, located ca. $400 \mathrm{~km} \mathrm{SE}$ of the main island group). Both live sightings (gold) and reported strandings (white) are shown, with circle diameter proportional to group size. The sighting described in the present study is also denoted with a red outline. The depth surface is derived from General Bathymetric Chart of the Oceans (GEBCO) available at 30 arc sec resolution (Becker et al. 2009). Basemap tile source: ESRI 
board the SVS Grenville in January and February 2017 (Caselle et al. 2018). The whales were detected on stereo mid-water Baited Remote Underwater Video Systems (BRUVS) (Bouchet et al. 2018; Bouchet and Meeuwig 2015; Letessier et al. 2013) suspended at a depth of 10 $\mathrm{m}$. The record was part of a broader survey that has deployed these BRUVS at 26 locations across the main islands of Tristan da Cunha, Nightingale, Inaccessible and Gough (Caselle et al. 2018). Each of these locations was sampled once with a set of 3 rigs, each separated by $200 \mathrm{~m}$ of line and baited with $1 \mathrm{~kg}$ of crushed fish. Mid-water BRUVS allow the sampling of any pelagic animals which enter the field of view, whether they are attracted to the bait or the rig structure, or just passing through by chance. This allows a wide range of shark and fish species from baitfish to top predators to be documented along with marine invertebrates, mammals, reptiles and even occasionally, seabirds (Bouchet et al. 2018). The two whales were recorded on the south-east side of Inaccessible Island, an uninhabited island located $35 \mathrm{~km}$ west-south-west of the island of Tristan da $\mathrm{Cu}$ nha. The BRUVS were deployed on the $27^{\text {th }}$ of January 2017 at $11: 18 \mathrm{am}(\mathrm{GMT})\left(37.32^{\circ} \mathrm{S}, 12.64^{\circ} \mathrm{W}\right)$ and retrieved at $1: 33 \mathrm{pm}(\mathrm{GMT})\left(37.32^{\circ} \mathrm{S}, 12.62^{\circ} \mathrm{W}\right)$ in conditions of strong winds and rain. The footage shows two individuals, one partially obscuring the other, swimming across the field of view of the cameras in a single pass, two minutes after the start of recording (Fig. 2; video footage available at (Thompson et al. 2018)). Neither animal was visibly attracted to the bait, nor observed from the research vessel.

The Shepherd's beaked whale is the only member of its genus, differing from other species in the Ziphiidae family in its full set of functional teeth in the upper and

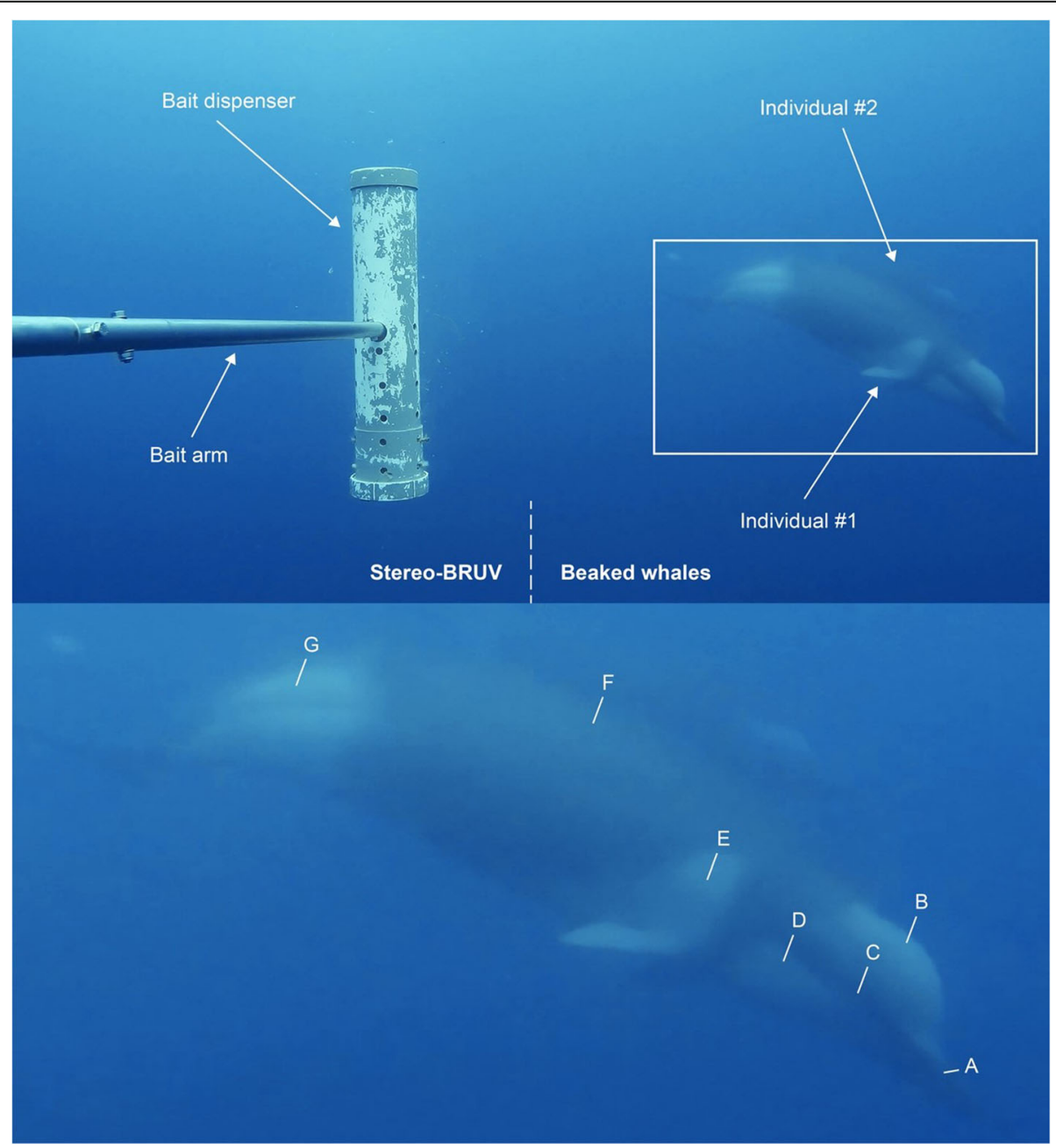

Fig. 2 Shepherd's beaked whales (Tasmacetus shepherdi), as observed on footage from mid-water stereo-BRUVS collected off the south-east coast of Inaccessible Island, Tristan da Cunha. Key diagnostic morphological features indicated are: a robust rostrum tapered towards the tip, b prominent, bulbous and pale melon, $\mathbf{c}$ mask-like area of darker colouration surrounding the eye, $\mathbf{d}$ white throat patch, e white blaze above pectoral fins, $\mathbf{f}$ dark dorsal cape and $\mathbf{g}$ lightly pigmented caudal peduncle 
lower jaws, and the non-appearance of the palatines in the palate. It is a medium-sized cetacean, with adults reaching lengths of 6-7 m and the only measured calf at $3.4 \mathrm{~m}$ (Mead 2002; Oliver 1937). It can be observed on the footage that the closer of the two individuals exhibits the key diagnostic morphological features of Shepherd's beaked whales as described in previous publications (Donnelly et al. 2018; Mead 2002; Pitman et al. 2006), namely (Fig. 2):

- A robust rostrum tapered towards the tip;

- A prominent, bulbous and pale melon rising steeply from about half way along the length of the gape;

- A mask-like area of darker colouration surrounding the eye;

- A white throat patch;

- A white blaze above the pectoral fins;

- A dark dorsal cape;

- A lightly pigmented caudal peduncle.

The second individual is less visible (Fig. 2). However, the features that can be distinguished match those of individual one and their close proximity suggest that they are likely the same species. Pitman et al. (2006) inferred from their observations that both sexes and all age classes are monomorphic with respect to skin colour, although this may be somewhat muted in younger animals. However, individual one does not show the dark flipper stripe described by Mead (2002), indicating that individual variation in pigmentation patterns may exist. Donnelly et al. (2018) suggest that there may be individual variation in the width of the blaze, and that this may be useful in identification. This observation supports the suggested variation of pigmentation in this region of the body and suggests that this variation may extend further than previously noted, leading to the complete absence of a flipper stripe in some individuals.

\section{Discussion}

Members of the Ziphiidae family comprise approximately $30 \%$ of the world's cetacean species, and although knowledge of their ecology has seen a substantial increase during the last two decades, many species remain little studied (Hernandez-Milian et al. 2017). Observations that document their occurrence and natural behaviour are therefore of significant value. It is possible that further records may be made as repeat deployments of mid-water BRUVS are undertaken in Tristan da Cunha in the future, under a long-term monitoring programme currently being developed by the University of Western Australia and the Tristan da Cunha Conservation Department. Underwater camera technology has been used to study a wide range of marine organisms, including sea snakes, turtles, rays, fishes and sharks (Letessier et al. 2015, 2013; Udyawer et al. 2014), and may be a useful addition to the suite of tools already used to observe rarely encountered whale species. For example, they could be deployed along with hydrophones to link vocalisations with species or in areas where passive acoustics indicate activity of species of interest. Detections of marine mammals on mid-water stereo-BRUVS are indeed not uncommon in offshore environments (Meeuwig J, unpublished observations), and are facilitated by an enhanced capacity to identify species based on footage of the animal's sides, which are seldom visible from the ocean surface (McLellan 2018). Stereo-BRUVS are also designed with two cameras mounted with convergent fields of view, which enable measurements of individual body lengths and body condition to be made via epipolar geometry (Harvey et al. 2003; Letessier et al. 2013). While in this case length and position estimates of sufficient quality could not be made due to high water turbidity, the ability to acquire such information in coming years will be important for refining understanding of beaked whale ontogeny, social behaviour and size structure.

Like other Ziphiids, the Shepherd's beaked whale is believed to use echolocation when foraging at depth (Johnson et al. 2004; Leunissen et al. 2018) and to feed predominantly on squid and fish (Hernandez-Milian et al. 2017). Existing dietary information supports this theory, but is limited to an examination of stomach contents of a single stranded female in Tristan da Cunha, which revealed 13 cephalopod and 8 fish species from beaks and otoliths respectively (Best et al. 2014). Our mid-water BRUVS dataset also allows an assessment of the pelagic community within which the whales live. Both the composition and relative abundance of fish assemblages observed were found to differ among islands (Caselle et al. 2018). Inaccessible Island was observed to have a tenth the number of fish of Tristan da Cunha, although average individual fish weight was three times higher. Additional surveys and concurrent deployments of deep water cameras at foraging depths (e.g. Deep Ocean Drop-cams) will aid in building a more complete picture of the overall assemblage, including the diversity and availability of possible prey species and competitors (Caselle et al. 2018; Turchik et al. 2015).

Straddling the subtropical convergence zone (Scott 2017), Tristan da Cunha attracts a variety of pelagic organisms (Caselle et al. 2018), including a number of marine mammals (Best et al. 2009). The islands, for instance, harbour the largest subantarctic fur seal (Arcocephalus tropicalis) population in the world (Bester et al. 2006), as well as a small breeding population of southern elephant seals (Mirounga leonina) (Bester et al. 2001). Killer whales (Orcinus orca) are also known to inhabit the region (Best et al. 2009), and have been documented 
to predate on beaked whales in other parts of the globe (Jefferson et al. 1991; Wellard et al. 2016). The relatively large proportion of records of Shepherd's beaked whales from Tristan da Cunha (16\% of reported strandings and $17 \%$ of live sightings) over a relatively small area suggests that this region may be an important year-round habitat for this species. Although the drivers of beaked whale presence (Pitman et al. 2006) remain unclear, a number of hypotheses can be formulated. One factor could be topographic complexity (Bouchet et al. 2015), which may provide both favourable foraging conditions through increased mixing and higher localised productivity, as well as sheltered coastal habitats of use in poor weather such as the leeward side of Inaccessible Island, at which these animals were recorded.

Fishing pressure in the Tristan da Cunha archipelago is relatively low (Booth and Azar 2009; Pauly and Zeller 2015), consisting primarily of a closely managed lobster fishery (Glass 2014). Additionally, a small-scale deepwater trawl fishery operates on seamounts outside a $50 \mathrm{~nm}$ buffer zone from the islands and pelagic longliners targeting tunas are sporadically issued licenses (Scott 2017). This lack of heavy fishing pressure, as well as the absence of other industrial activities, may make the region a relatively favourable habitat by lowering the likelihood of negative interactions with fishing gear and vessels, and reducing pressure on primary food sources (squid and fish) (Best et al. 2014; Weilgart 2007a). However, no region of the ocean is completely free of human impacts (Halpern et al. 2015, 2008), and intensifying shipping traffic through the Tristan da Cunha Exclusive Economic Zone (EEZ) presents an emerging threat from increased noise pollution and elevated risks of strike-related injuries and/or mortality. Ziphiids are known to be particularly susceptible to anthropogenic noise, to which they respond by altering their vocalizations, respiration rates, swim speeds, diving patterns, and movement behaviour (Tyack et al. 2011). Chronic exposure to noise has also been shown to result in displacement, avoidance, shifts in migration path, stress, hearing damage and strandings (Weilgart 2007a, b). Greater understanding of the distribution patterns of the Shepherd's beaked whale throughout the region is thus critical to mitigating these impacts (Bell et al. 2018). Ongoing sampling with mid-water BRUVS may complement surface sightings and strandings data to provide more comprehensive information on the distribution patterns of this species, as well as providing insights into the pelagic community of which they are part.

\section{Acknowledgments}

The authors thank the National Geographic Society Pristine Seas programme for funding and executing the expedition and the Royal Society for the Protections of Birds, for their partnership. We would like to thank J. Caselle for her dedicated leadership of the science programme during the expedition and P. Rose, J. Hall, A. Schofield, D. McAloney, S. Dews, and D. Meyer for their leadership and logistical support. We appreciate the hard work and dedication of the crew of the SVS Grenville and extend our sincere gratitude to the people of Tristan da Cunha who welcomed our team to their islands, and who provided exceptional expertise on the water and assistance with research logistics. In particular, we would like to thank Tristanians James Glass, Trevor Glass, Ian Lavarello, Rodney Green, George Swain and Julian Repetto for their fantastic assistance in the field, which was integral to making our sampling effective, and Sean Burns for island hospitality.

\section{Funding}

The expedition on which this observation was made was funded by National Geographic Pristine Seas and The Royal Society for the Protection of Birds.

\section{Availability of data and materials}

The datasets used and/or analysed during the current study are available from the corresponding author on reasonable request.

\section{Authors' contributions}

$\mathrm{CT}$ collected and analysed the video footage, and produced the draft manuscript. PB produced the figures and provided input on the manuscript. JM provided input and guidance on the manuscript. All authors read and approved the final manuscript.

\section{Ethics approval and consent to participate}

All relevant approvals and permits were obtained for the remote camera work conducted in Tristan da Cunha, University of Western Australia ethics protocols were followed (approval number RA/3/100/1484).

\section{Consent for publication}

Not applicable.

\section{Competing interests}

The authors declare that they have no competing interests.

\section{Publisher's Note}

Springer Nature remains neutral with regard to jurisdictional claims in published maps and institutional affiliations.

\section{Author details}

${ }^{1}$ Marine Futures Lab, School of Biological Sciences M092, The University of Western Australia, Crawley, WA 6009, Australia. ${ }^{2}$ School of Ocean Sciences, Bangor University, Menai Bridge LL59 5AB, UK.

Received: 24 September 2018 Accepted: 8 March 2019

Published online: 21 March 2019

\section{References}

Becker JJ, Sandwell DT, Smith WHF, Braud J, Binder B, Depner J, et al. Global bathymetry and elevation data at 30 arc seconds resolution: SRTM30_PLUS. Mar Geod. 2009:32(4):355-71.

Bell J, Stamford T, Hall J, Burns S, Butcher R, Bell J, et al. Report on the Tristan da Cunha marine protection planning workshop. 2018.

Best PB, Glass JP, Ryan PG, Dalebout ML. Cetacean records from Tristan da Cunha, South Atlantic. J Mar Biol Assoc U K. 2009;89(5):1023-32.

Best PB, Smale MJ, Glass J, Herian K, Von Der Heyden S. Identification of stomach contents from a Shepherd's beaked whale Tasmacetus shepherdi stranded on Tristan da Cunha, South Atlantic. J Mar Biol Assoc U K. 2014;94(6):1093-7.

Bester MN, Möller H, Wium J, Enslin B, Moller H, Wium J, et al. An update on the status of southern elephant seals at Gough Island. S Afr J Wildl Res. 2001; 31(1):68-71.

Bester MN, Wilson JW, Burle M-H, Hofmeyr GJG. Population trends of subantarctic fur seals and southern elephant seals at Gough Island. S Afr J Antarct Res. 2006:20(1):9-12.

Booth S, Azar H. The fisheries of St Helena and its dependencies. Fish. catch Reconstr. Islands, Part 1; 2009.

Bouchet P, Meeuwig J, Huveneers C, Langlois T, Letessier T, Lowry M, Rees M, Santana-Garcon J, Scott M, Taylor M, Thompson C, Vigliola L, Whitmarsh S. Marine sampling field manual for pelagic BRUVS (Baited Remote Underwater 
Videos). In: Field Manuals for Marine Sampling to Monitor Australian Waters. National Environmental Science Programme (NESP); 2018. p. 105-132.

Bouchet PJ, Meeuwig JJ. Drifting baited stereo-videography: a novel sampling tool for surveying pelagic wildlife in offshore marine reserves. Ecosphere. 2015;6(8):art137.

Bouchet PJ, Meeuwig JJ, Salgado Kent CP, Letessier TB, Jenner CK. Topographic determinants of mobile vertebrate predator hotspots: current knowledge and future directions. Biol Rev. 2015;90(3):699-728.

Caselle JE, Hamilton SL, Davis K, Thompson CDH, Turchik A, Jenkinson R, et al. First quantification of subtidal community structure at Tristan da Cunha Islands in the remote South Atlantic: from kelp forests to the deep sea. PLOS ONE. 2018;13(3):e0195167.

Donnelly DM, Ensor P, Gill P, Clarke RH, Evans K, Double MC, et al. New diagnostic descriptions and distribution information for Shepherd's beaked whale ( Tasmacetus shepherdi ) off Southern Australia and New Zealand. Mar Mammal Sci. 2018;00(00):1-12.

Glass JP. The fishery and biology of the rock lobster Jasus tristani at the Tristan da Cunha island group; 2014.

Halpern BS, Frazier M, Potapenko J, Casey KS, Koenig K, Longo C, et al. Spatial and temporal changes in cumulative human impacts on the world's ocean. Nat Commun. 2015;6:1-7.

Halpern BS, Walbridge S, Selkoe KA, Kappel CV, Micheli F, D'Agrosa C, et al. A global map of human impact on marine ecosystems. Science. 2008; 319(5865):948-52

Harvey E, Cappo M, Shortis M, Robson S, Buchanan J, Speare P. The accuracy and precision of underwater measurements of length and maximum body depth of southern bluefin tuna (Thunnus maccoyii) with a stereo-video camera system. Fish Res. 2003;63(3):315-26.

Hernandez-Milian G, Lusher A, O'Brian J, Fernandez A, O'Connor I, Berrow S, et al. New information on the diet of True's beaked whale (Mesoplodon mirus, gray 1850), with insights into foraging ecology on mesopelagic prey. Mar Mammal Sci. 2017;33(4):1245-54.

Hevia M, Arcucci D, Belgrano J, Cipriano F, Failla M, Gasparrou C, et al. Strandings of six beaked whales in Santa Cruz province, southern Argentina (1998-2011). J Cetacean Res Manag. 2012;SC/63/SM3:1-8.

Holyoake C, Holley D, Spencer PBS, Salgado-Kent C, Coughran D, Bejder L. Northernmost record of Shepherd's beaked whale (Tasmacetus shepherdi) - a morphological and genetic description from a stranding from Shark Bay. W Aust Pacific Conserv Biol. 2013;19:169-74

Jefferson TA, Stacy P, Baird RW. A review of killer whale interactions with other marine mammals: predation to co-existence. Mamm Rev. 1991;21(4):151-80.

Johnson M, Madsen PT, Zimmer WMX, Aguilar de Soto N, Tyack PL. Beaked whales echolocate on prey. Proc R Soc Lond Ser B Biol Sci. 2004;271(Suppl 6):S383-6.

Kaschner K, Ready JS, Agbayani E, Rius J, Kesner-Reyes K, Eastwood PD, et al. AquaMaps: Predicted range maps for aquatic species. World wide web Electron. Publ. www. aquamaps. org, Version, 8, p.2010. 2008

Kaschner K, Watson R, Trites AW, Pauly D. Mapping world-wide distributions of marine mammal species using a relative environmental suitability (RES) model. Mar Ecol Prog Ser. 2006;316:285-310.

Letessier TB, Bouchet PJ, Reisser J, Meeuwig JJ. Baited videography reveals remote foraging and migration behaviour of sea turtles. Mar Biodivers. 2015; 45(4):609-10.

Letessier TB, Meeuwig JJ, Gollock M, Groves L, Bouchet PJ, Chapuis L, et al. Assessing pelagic fish populations: the application of demersal video techniques to the mid-water environment. Methods Oceanogr. 2013;8:41-55.

Leunissen EM, Webster T, Rayment W. Characteristics of vocalisations recorded from free-ranging Shepherd's beaked whales, Tasmacetus shepherdi. J Acoust Soc Am. 2018;144(5):2701-8.

MacLeod C, Perrin W, Pitman RL, Barlow J, Ballance LT, D'Amico A, et al. Known and inferred distributions of beaked whale species ( Cetacea: Ziphiidae ). J Cetacean Res Manag. 2006;7(3):271-86.

McLellan W. Distribution and abundance of beaked whales (family Ziphiidae) off Cape Hatteras, North Carolina. USA Mar Mammal Sci. 2018;00(00):1-21.

Mead JC. Encyclopedia of Marine Mammals: Beaked Whale Overview. San Diego: San Diego Academic Press; 2002. p. 81-4.

Mead JG. Handbook of marine mammals: Beaked whales of the genus Mesoplodon. London: London Academic Press; 1989. p. 349-430.

Miller BS, Kelly N, Double MC, Childerhouse SJ, Laverick S, Gales N. Cruise report on SORP 2012 blue whale voyages: Development of acoustic methods. Rep Submitt Sci Comm Int Whal Comm. 2012;64/SH11:16.
Oliver WRB. Tasmacetus shepherdi: a new Genus and Species of Beaked Whale from New Zealand. Proc Zool Soc Lond. 1937;107(3):371-82.

Pauly D, Zeller D. Catch reconstruction: concepts, methods and data sources. Online Publ. Sea Around Us. Univ. Br. Columbia. 2015. Available from: www. seaaroundus.org

Pitman RL, Van Helden AL, Best PB, Pym A. Shepherd's beaked whale (Tasmacetus shepherdi): information on appearance and biology based on strandings and at-sea observations. Mar Mammal Sci. 2006;22(3):744-55.

Scott S. A biophysical profile of the Tristan da Cunha archipelago; 2017.

Taylor BL, Baird R, Barlow J, Dawson SM, Ford J, Mead JG, et al. Tasmacetus shepherdi: IUCN Red List Threat. Species; 2008. Available from: https://doi.org/ 10.2305/IUCN.UK.2008.RLTS.T21500A9291409.en

Thompson CDH, Bouchet PJ, Meeuwig JJ. Video Footage: First sub-surface sighting of Shepherd's beaked whales T. shepherdi. 2018. Available from: https://youtu.be/cW_iKoPOyTQ

Turchik AJ, Berkenpas EJ, Henning BS, Shepard CM. The Deep Ocean Dropcam: a highly deployable benthic survey tool; 2015.

Tyack PL, Zimmer WMX, Moretti D, Southall BL, Claridge DE, Durban JW, et al. Beaked whales respond to simulated and actual navy sonar. PLoS One. 2011; 6(3):e17009.

Udyawer V, Cappo M, Simpfendorfer CA, Heupel MR, Lukoschek V. Distribution of sea snakes in the great barrier reef Marine Park: observations from 10 yrs of baited remote underwater video station (BRUVS) sampling. Coral Reefs. 2014; 33(3):777-91.

Weilgart LS. The impacts of anthropogenic ocean noise on cetaceans and implications for management. Can J Zool. 2007a;85(11):1091-116.

Weilgart LS. A brief review of known effects of noise on marine mammals. Mar Ecol Prog Ser. 2007b;351(2):301-10.

Wellard R, Lightbody K, Fouda L, Blewitt M, Riggs D, Erbe C. Killer whale (Orcinus orca) predation on beaked whales (Mesoplodon spp.) in the Bremer SubBasin, Western Australia. PLoS One. 2016;11(12):15-7.

\section{Ready to submit your research? Choose BMC and benefit from:}

- fast, convenient online submission

- thorough peer review by experienced researchers in your field

- rapid publication on acceptance

- support for research data, including large and complex data types

- gold Open Access which fosters wider collaboration and increased citations

- maximum visibility for your research: over $100 \mathrm{M}$ website views per year

At BMC, research is always in progress.

Learn more biomedcentral.com/submissions 